\title{
1 Arsenic in Peruvian rice cultivated in the major rice growing region of Tumbes river \\ 2 basin
}

$3{\text { Debapriya } \text { Mondal }^{1 *} \text {, Romy Periche }}^{2}$, Bristin Tineo ${ }^{2}$, Luis A. Bermejo ${ }^{2}$, Mohammad

4 Mahmudur Rahman ${ }^{3}$, Abu Bakkar Siddique ${ }^{3}$, Md. Aminur Rahman ${ }^{3}$, José L. Solis ${ }^{4}$ and

5 Gerardo J.F. Cruz ${ }^{2}$

$6{ }^{1}$ School of Science, Engineering and Environment, University of Salford, UK

$7 \quad{ }^{2}$ Department of Forestry Engineering and Environmental Management, Universidad

8 Nacional de Tumbes, Av. Universitaria s/n, Pampa Grande, Tumbes, Peru

$9{ }^{3}$ Global Centre for Environmental Remediation (GCER), Faculty of Science, The University

10 of Newcastle, Newcastle, NSW 2308, Australia

$11{ }^{4}$ Faculty of Science, Universidad Nacional de Ingeniería, Av. Túpac Amaru 210, Lima 25,

12 Peru

13 Corresponding author* $\underline{\text { d.mondal @ salford.ac.uk }}$

Abstract

Arsenic (As) exposure from surface and groundwater in Peru is being recognised as a potential threat but there are limited studies on As in the food-chain and none on As in Peruvian rice. In this study, we have determined the As content in rice cultivated in the Tumbes river basin located in the northern province of Peru, an area known for extensive rice cultivation. We collected rice and soil samples from agricultural fields, soil was collected using grid sampling technique while rice was collected from the heaps of harvested crop placed across the fields. The average total As concentration in rice was $167.94 \pm 71 \mu \mathrm{g} \mathrm{kg}^{-1}$ $\left(\mathrm{n}=29\right.$; range 68.39-345.31 $\mu \mathrm{g} \mathrm{kg}^{-1}$ ). While the rice As levels were not highly elevated, the As content of few samples $(\mathrm{n}=7)$ greater than $200 \mu \mathrm{g} \mathrm{kg}^{-1}$ could contribute negatively to human 
health upon chronic exposure. Average concentration of As in soil was $8.63 \pm 7.8 \mathrm{mg} \mathrm{kg}^{-1}$ $(\mathrm{n}=30)$ and soil to grain transfer factor was $0.025 \pm 0.018$ for 12 matched samples. Compared to our previous pilot study in 2006 (samples collected from the same agricultural fields but not from exact locations) there was a $41 \%$ decrease in As soil concentration in this study. Rice samples collected in $2006(\mathrm{n}=5)$ had a mean concentration of $420 \pm 109 \mu \mathrm{g} \mathrm{kg}^{-1}$. Our data provides a baseline of rice grain As concentrations in Peruvian province of Tumbes and warrants further studies on factors affecting uptake of As by the rice varieties cultivated in Peru and any potential human health risks.

Key words: arsenic; rice; soil; Tumbes river basin; Peru; Latin America

\section{Introduction}

Arsenic (As) has emerged as a major global health concern in the last few decades due to its serious impact on human health. Though the problem of As contamination has been well studied in some of the Latin American countries which have a long history of widespread As contamination, this is not so true for Peru. While As exposure in Peru, was first reported in the Ilo valley in 1970 (Bundschuh et al., 2012a) there are very few studies on As exposure in Andean river basins and none, to best of our knowledge on As contamination of the northern coastal region of Peru - the Tumbes river basin.

It was once roughly estimated that 250,000 Peruvian were exposed to As (McClintock et al., 2012) but there is no systematic exposure or health risk assessment. In most areas, As is predominantly released due to mining activities or natural weathering and transported by the river. These river waters are predominantly used for irrigation apart from drinking purposes (Bundschuh et al., 2012b). In a 2014 study, 77\% of the ground drinking water samples collected from twelve districts of Peru $(n=151)$ were found to exceed the WHO recommended limit of $10 \mu \mathrm{g} \mathrm{L}^{-1}$ with maximum recorded As concentration of $193.1 \mu \mathrm{g} \mathrm{L}^{-1}$ 
(George et al., 2014). Peruvian National Authority of Water found As concentrations reaching up to $1174 \mu \mathrm{g} \mathrm{L}^{-1}$ in filtered water of Tumbes river between 2011 - 2016 (Silva, 2018) flowing from Ecuadorian provinces (where it is called Puyango river) into Tumbes district of Peru. But Tumbes was not among the twelve districts surveyed in the George et al. (2014) study. In a recent study, the majority of the water and sediment samples collected from the Puyango-Tumbes river had elevated concentrations of As along with mercury $(\mathrm{Hg})$, cadmium $(\mathrm{Cd})$, copper $(\mathrm{Cu})$, lead $(\mathrm{Pb})$ and zinc $(\mathrm{Zn})$ exceeding the Canadian Council of Ministers of the Environment thresholds for the Protection of Aquatic Life (Marshall et al., 2018). Puyango-Tumbes river is the only available water source in the semi-arid region of northern Peru (Marshall et al., 2018) and similar to other Peruvian river basins, the main source of irrigation and drinking water.

The Puyango-Tumbes river basin encompasses a large diverse land area $(90,000$ ha in Tumbes) essentially devoted to agriculture, where more than 6000 farmers are engaged in cultivation, predominantly of rice along with banana, corn and other fruits (Marshall et al., 2018). The Tumbes river is an important source of water for irrigation, hence pollutants discharged from mining and other activities in the upper course of the river (Puyango in Ecuador) including As, pose a significant health risk to those consuming food, cultivated in these lands. Compared to other crops, rice has a high ability to absorb As from the soil, making it the most contaminated cereal (Meharg and Zhao, 2012) and consumption of rice is a well-established route of As exposure (Mondal and Polya, 2008; Mondal et al., 2010). Agriculture being an important part of the economy in Tumbes, with one of the dominant crops being rice, assessment of As is rice cultivated in Tumbes river basin is of significance. Moreover, unlike other Latin American countries, little is known about the As in food-chain of Peru (Bundschuh et al., 2012b) and none about rice. In this study we have determined the As content in rice cultivated in the Tumbes river basin of Peru and compared the findings 
with a preliminary pilot data collected by us in 2006 (Bermejo and Cruz, 2006). We have also estimated As and other potentially toxic elements present in the agricultural soil and irrigation water of Tumbes river basin and calculated the transfer factor between soil and the grain.

\section{Methods}
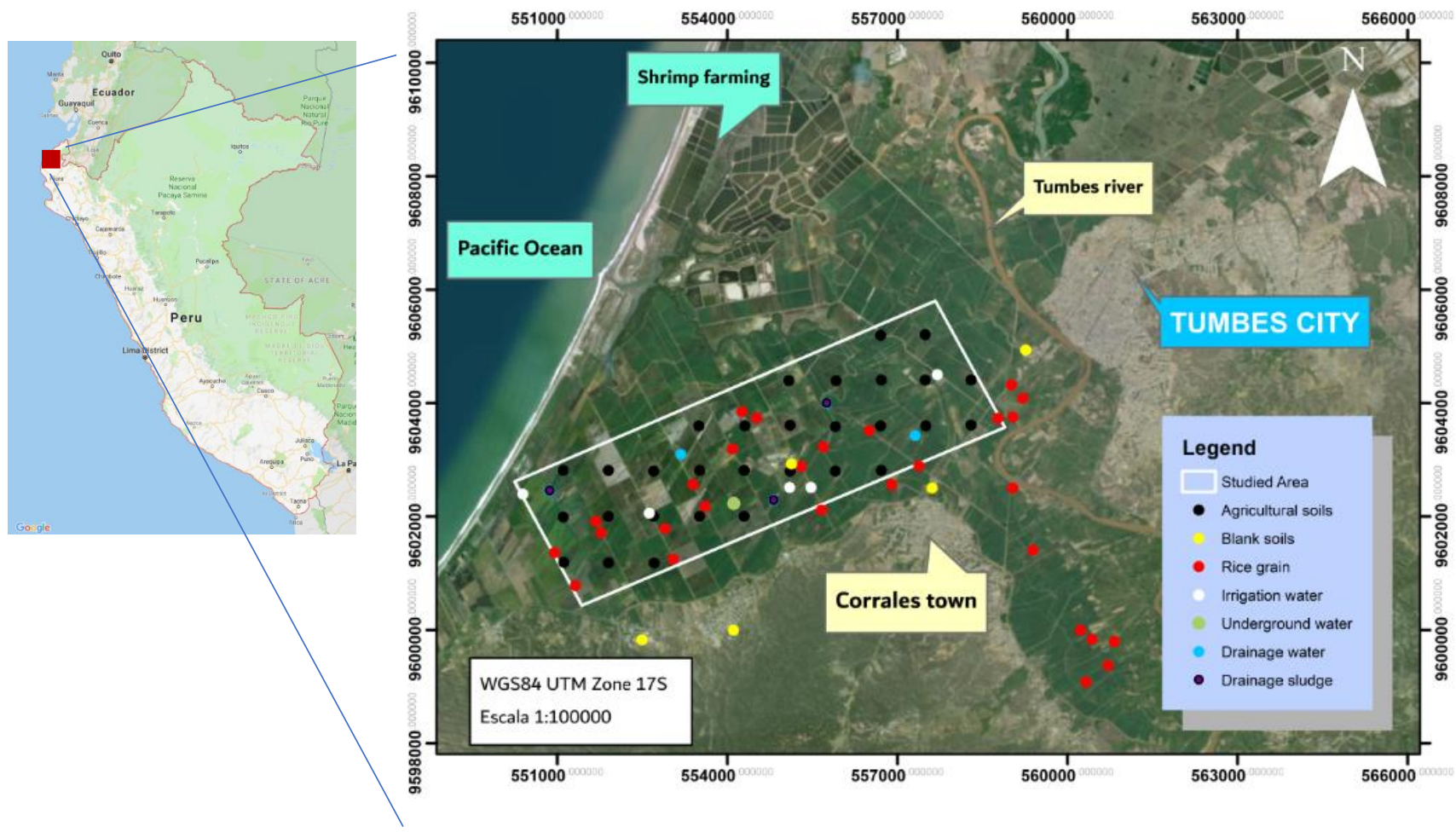

Figure 1: Sampling location for all the different samples collected

\subsection{Sample collection and analysis:}

Figure 1 shows the sampling site for this study within the paddy cultivation fields covering 2100 ha in Tumbes river basin located in the northern province of Peru. Rice samples $(n=29)$ were collected from the heaps of harvested crop placed across the agricultural field from locations shown in Figure 1. All the samples (husked rice and grain separated), were washed, dried, grinded to powder using a porcelain mortar to avoid contamination and then stored in zip-lock bags. 
91 Agricultural soil samples $(n=30)$ were collected by grid sampling technique overlaying a rectangular grid of $8088 \mathrm{~m}$ by $2600 \mathrm{~m}$ over the rice fields as shown in Figure 1. A single soil core of $30 \mathrm{~cm}$ square and $30 \mathrm{~cm}$ deep was collected at a grid spacing distance of $800 \mathrm{~m}$ over 30 different locations (Figure 1). The $\mathrm{pH}$, redox potential (Eh) and textural properties (content of lime, clay and sand) were analysed for all agricultural soil samples. Both $\mathrm{pH}$ and Eh were measured using potentiometer (Inolab pH 7310 WTW (Merck, Germany)) after making a soil suspension ( $5 \mathrm{~g}$ of the agricultural soil was mixed with $50 \mathrm{~mL}$ of water, agitated for 30 minutes and then left for $1 \mathrm{~h}$ before vacuum filtration) while the soil texture was measured by hydrometer method. The soil (roughly $2 \mathrm{~kg}$ ) were homogenised, sieved through ASTM $\mathrm{N}^{\circ} 100(150 \mu \mathrm{m})$, oven dried at $80^{\circ} \mathrm{C}$ and stored in zip-lock bags. In order to compare the content of As and potentially toxic elements in samples of agricultural soils inside the paddy fields with those outside the paddy fields, control (blank) samples $(n=5)$ were taken (two were taken from the hills covered by dry forest close to the agricultural fields; one from similar agricultural area but outside the paddy fields; one from a local area close to the river near the Corrales town: and one sample was taken inside the studied area, but from a location in between the paddy fields). These samples were collected, homogenised, dried and stored similar to the agricultural soils. Samples of irrigation $(n=5)$ and drainage water (the water coming out of the paddy field; $n=5$ ) along with the ground water $(n=1)$ were taken from the study area. $20 \mathrm{~mL}$ of the water samples were taken from the source and filtered using a $20 \mathrm{~mL}$ syringe filter fitted with Whatman 41 filter paper, and then acidified using $0.2 \mathrm{~mL}$ of concentrated nitric acid (65\% vol). Drainage sludge samples were collected $(n=3)$ from the drainage system while sampling the drainage water and then they were dried, grinded and sieved following the same protocol as for the agricultural soils.

Rice and soil samples were analysed at The University of Newcastle, Australia following the established protocols. Briefly, rice samples were digested for the analysis of total As and 
other elements based on the protocol of Roychowdhury et al. (2002) while a microwave assisted digestion system (model: MARS 5, CEM) was used for the digestion of soil using the USEPA 3051A method (USEPA, 2007). Determination of As and other trace metals (Cd, $\mathrm{Cu}, \mathrm{Pb}, \mathrm{Zn}$, antimony $(\mathrm{Sb})$, barium $(\mathrm{Ba})$, boron $(\mathrm{B})$, cobalt $(\mathrm{Co})$, chromium $(\mathrm{Cr})$, manganese (Mn), selenium (Se), Strontium (Sr) and vanadium (V)) was carried out with an Agilent 7900 (Agilent Technologies, Tokyo, Japan) inductively coupled plasma mass spectrometer (ICPMS) coupled with an autosampler (Agilent Technologies). Major elements such as calcium $(\mathrm{Ca})$, magnesium $(\mathrm{Mg})$, sodium $(\mathrm{Na})$, aluminium $(\mathrm{Al})$, iron $(\mathrm{Fe})$ were analyzed using the dual view (Axial and radial) inductively coupled plasma emission spectrometer (ICP-OES, PerkinElmer Avio 200, USA). CRM, blanks, duplicates, and continuing calibration verification $(\mathrm{CCV})$ were included in each batch throughout the elemental analysis. Standard reference materials (SRM) from the National Institute of Standards and Technology (NIST), USA (Rice flour (SRM 1568b) and Montana soil (SRM 2711a)) were used. Water samples were analyzed at the University of Salford using ICP-OES Varian 720-ES (California, USA).

\subsection{Data analysis:}

Data was analyzed using Microsoft Excel and Stata 11.2 for descriptive statistics and for independent t-test. The multivariate principal component analysis (PCA) technique was applied to the soil data, in order to explore the grouping of elements according to their similarities and the analysis was performed using Stata 11.2. The spatial distribution of elements in soil for the study area was developed using Surfer 18 (Golden Software, Colorado, EEUU). The grids used as bases to build contour maps were done using interpolation with the kriging method (no data was assigned outside convex hull of data). Based on these grids, the contour maps for every element were developed. The transfer factor between soil and grain (TFgrain/soil = concentration in grain/concentration is soil) was 
141 (Figure 1).

\section{Results and discussion}

\subsection{Quality control}

Mean total recoveries $(n=5)$ from both rice and soil SRMs were within the range of $80-120 \%$ recoveries were between $92-115 \%$ for all elements.

Table 1: Percentage recovery of As and other elements in NIST SRMs ( $n=5$ for both rice and soil)

149

\begin{tabular}{|c|c|c|c|c|c|c|}
\hline \multirow[t]{2}{*}{ Elements } & \multicolumn{3}{|c|}{ NIST SRM 1568b (Rice flour) } & \multicolumn{3}{|c|}{ NIST SRM 2711a (Montana soil) } \\
\hline & $\begin{array}{l}\text { Certified } \\
\text { values }\end{array}$ & $\begin{array}{l}\text { Measured } \\
\text { values }\end{array}$ & $\begin{array}{c}\text { Recovery } \\
(\%)\end{array}$ & Certified values & Measured values & $\begin{array}{l}\text { Recovery } \\
(\%)\end{array}$ \\
\hline As $\left(\mu \mathrm{g} \mathrm{kg}^{-1}\right)$ & $285 \pm 14$ & $261 \pm 5.6$ & 92 & $107,000 \pm 5000$ & $99,000 \pm 4000$ & 92 \\
\hline $\mathrm{V}\left(\mu \mathrm{g} \mathrm{kg}^{-1}\right)$ & - & & & $80,700 \pm 5700$ & $69,000 \pm 3100$ & 85 \\
\hline $\mathrm{Cr}\left(\mu \mathrm{g} \mathrm{kg}^{-1}\right)$ & - & & & $52,300 \pm 2900$ & $41,000 \pm 3000$ & 78 \\
\hline $\operatorname{Co}\left(\mu \mathrm{g} \mathrm{kg}^{-1}\right)^{\mathrm{a}}$ & $17.7 \pm 0.05$ & $15.2 \pm 1.44$ & 86 & $9890 \pm 180$ & $9300 \pm 910$ & 94 \\
\hline $\mathrm{Ni}\left(\mu \mathrm{g} \mathrm{kg}^{-1}\right)$ & - & & & $21,700 \pm 700$ & $19,100 \pm 2300$ & 88 \\
\hline $\operatorname{Se}\left(\mu \mathrm{g} \mathrm{kg}^{-1}\right)$ & $365 \pm 29$ & $347 \pm 18$ & 95 & 2000 & 4000 & \\
\hline $\mathrm{Cd}\left(\mu \mathrm{g} \mathrm{kg}^{-1}\right)$ & $22.4 \pm 1.3$ & $21.9 \pm 2.9$ & 98 & $54,100 \pm 500$ & $47,000 \pm 1065$ & 86 \\
\hline $\mathrm{Sb}\left(\mu \mathrm{g} \mathrm{kg}^{-1}\right)$ & - & & & $23,800 \pm 1400$ & $19,000 \pm 457$ & 80 \\
\hline $\mathrm{Pb}\left(\mu \mathrm{g} \mathrm{kg}^{-1}\right)^{\mathrm{a}}$ & $8 \pm 3$ & $52 \pm 2.5$ & & $0.140 \pm 0.001^{\mathrm{b}}$ & $0.144 \pm 0.16$ & 102 \\
\hline $\operatorname{Mn}\left(\mathrm{mg} \mathrm{kg}^{-1}\right)$ & $19.2 \pm 1.8$ & $16.8 \pm 2.9$ & 88 & $675,000 \pm 18,000$ & $589,000 \pm 3600$ & 87 \\
\hline $\mathrm{Cu}\left(\mathrm{mg} \mathrm{kg}^{-1}\right)$ & $2.35 \pm 0.16$ & $2.11 \pm 0.07$ & 89 & $140,000 \pm 2000$ & $121,000 \pm 2000$ & 86 \\
\hline $\mathrm{Zn}\left(\mathrm{mg} \mathrm{kg}^{-1}\right)$ & $\begin{array}{l}19.42 \pm \\
0.26\end{array}$ & $17.36 \pm 0.14$ & 89 & $414,000 \pm 11,000$ & $385,000 \pm 4900$ & 93 \\
\hline $\mathrm{Al}\left(\mathrm{mg} \mathrm{kg}^{-1}\right)$ & $4.21 \pm 0.34$ & $3.80 \pm 1.21$ & 90 & $6.72 \pm 0.06^{b}$ & $5.10 \pm 0.07$ & 76 \\
\hline $\mathrm{Ca}\left(\mathrm{mg} \mathrm{kg}^{-1}\right)$ & $118.4 \pm 3.1$ & $116.2 \pm 4.0$ & 98 & $2.42 \pm 0.06^{\mathrm{b}}$ & $1.93 \pm 0.02$ & 79.7 \\
\hline $\mathrm{Fe}\left(\mathrm{mg} \mathrm{kg}^{-1}\right)$ & $7.42 \pm 0.44$ & $6.24 \pm 0.25$ & 84 & $2.82 \pm 0.04^{\mathrm{b}}$ & $2.51 \pm 0.06$ & 89 \\
\hline $\mathrm{K}\left(\mathrm{mg} \mathrm{kg}^{-1}\right)$ & $1282 \pm 11$ & $1129 \pm 23$ & 88 & $2.53 \pm 0.10^{b}$ & $2.37 \pm 0.01$ & 94 \\
\hline $\mathrm{Mg}\left(\mathrm{mg} \mathrm{kg}^{-1}\right)$ & $559 \pm 10$ & $462 \pm 9$ & 83 & $1.07 \pm 0.06^{b}$ & $0.95 \pm 0.01$ & 89 \\
\hline $\mathrm{Ba}\left(\mathrm{mg} \mathrm{kg}^{-1}\right)$ & - & & & $730,000 \pm 15,000$ & $\begin{array}{l}572,000 \pm \\
14,300\end{array}$ & 78 \\
\hline $\mathrm{Na}\left(\mathrm{mg} \mathrm{kg}^{-1}\right)$ & $6.74 \pm 0.19$ & $29.1 \pm 4.7$ & & $1.2 \pm 0.01^{\mathrm{b}}$ & $0.7 \pm 0.06$ & 58 \\
\hline $\mathrm{Sr}\left(\mathrm{mg} \mathrm{kg}^{-1}\right)$ & - & & & $242,000 \pm 10,000$ & $235,000 \pm 3800$ & 97 \\
\hline
\end{tabular}




\subsection{Arsenic in Peruvian rice}

152 This is the first study reporting As concentrations in rice cultivated in Peru (Table 2). When compared with other Latin American countries, the average total As concentration in 29 rice samples $167.94 \pm 71 \mu \mathrm{g} \mathrm{kg}^{-1}$ (range $68.39-345.31 \mu \mathrm{g} \mathrm{kg}^{-1}$ ) was higher than reported concentrations in rice cultivated in Guayas and Los Ríos provinces of Ecuador $(125 \pm 44 \mu \mathrm{g}$ $\mathrm{kg}^{-1}$ in Guayas; $42 \pm 33 \mu \mathrm{g} \mathrm{kg}^{-1}$ from Los Ríos and $67 \pm 29 \mu \mathrm{g} \mathrm{kg}^{-1}$ from the market) (Otero et al., 2016) but similar to total As in Brazilian husked rice from Santa Catarina (157 $\pm 108 \mu \mathrm{g}$ $\mathrm{kg}^{-1} ; 70-427 \mu \mathrm{g} \mathrm{kg}^{-1}$ ); while lower than the concentrations in rice from Rio Grande do Sul $\left(235 \pm 157 \mu \mathrm{g} \mathrm{kg}^{-1} ; 20-630 \mu \mathrm{g} \mathrm{kg}^{-1}\right)$ (Kato et al., 2019). In a review, Bundschuh et al. (2012b)(based on the published results of Juarez-Soto's MSc thesis) summarised As concentrations in food chain, other than rice and reported As in edible plants collected from Rímac river, Carapongo in Peru in the range of 51-121 $\mu \mathrm{g} \mathrm{kg}^{-1} ; 33-512 \mu \mathrm{g} \mathrm{kg}^{-1}$ and 40-193 $\mu \mathrm{g} \mathrm{kg}^{-1}$ by wet weight in radish, lettuce and beet respectively.

While the maximum total As recorded was $345.31 \mu \mathrm{g} \mathrm{kg}^{-1}, 7$ out of 29 rice samples had total As greater than $200 \mu \mathrm{g} \mathrm{kg}^{-1}$. The Joint FAO-WHO Codex Alimentarius Commission in July 2014 established a maximum level of $200 \mu \mathrm{g} \mathrm{kg}^{-1}$ for inorganic As in polished rice (EFSA, 2014) but in a population based study, Banerjee et al. (2013) reported elevated genotoxic effects in a population from West Bengal, India, consuming cooked rice with total As greater method (Rahman et al., 2006; Mwale et al., 2018). In Peru, rice is often cooked with vegetable oil, garlic, salt and limited water (water to rice ratio less than 2:1) which is then evaporated to dryness. Removal of As on cooking with uncontaminated water is least when rice is cooked with limited water and the water is evaporated (Mwale et al., 2018). Based on total annual per capita rice consumption of $51.6 \mathrm{~kg}_{\text {person }}{ }^{-1}$ in coastal areas of Peru (INEI, 
2012), amount of rice consumed per day would be approximately $141.37 \mathrm{~g}$. Considering inorganic As content of the rice to be $80 \%$, as observed in Ecuadorian rice by Otero et al. (2016), for an average weight of $70 \mathrm{~kg}$ person, consuming rice cultivated in Tumbes river basin (average total As in rice of $168 \mu \mathrm{g} \mathrm{kg}^{-1}$ ) the ADI (average daily intake) of inorganic As would be $0.27 \mu \mathrm{g}(\mathrm{kg} \mathrm{bw})^{-1} \mathrm{~d}^{-1}$, but the maximum intake could reach up to $0.56 \mu \mathrm{g}(\mathrm{kg} \mathrm{bw})^{-1}$ $\mathrm{d}^{-1}$ (based on maximum As concentration of $345 \mu \mathrm{g} \mathrm{kg}^{-1}$ in rice). This estimated ADI is safe considering the European Food Safety Authority recommended range of inorganic As exposure of 0.3-8 $\mu \mathrm{g}(\mathrm{kg} \mathrm{bw})^{-1} \mathrm{~d}^{-1}$ based on $1 \%$ increased incidence in lung, skin and bladder cancer and skin lesions ((Mondal et al. (2019) from Cubadda et al. (2017)). But further studies addressing As speciation in Peruvian rice, As in cooked rice, accurate rice intake by the local population and risk perception of As exposure from rice intake (Mondal et al., 2019) can elucidate the increased health risk, if any due to As in Peruvian rice.

Table 2: Total As and concentrations of other elements in rice grains $(n=29)$ collected from agricultural fields of Tumbes river basin in Peru.

\begin{tabular}{|c|c|c|c|c|}
\hline Elements & $\begin{array}{c}\text { Average } \pm \text { Std. } \\
\text { Dev }\end{array}$ & Median & Range & Spearman rho $^{\mathrm{a}}$ \\
\hline $\mathrm{As}\left(\mu \mathrm{g} \mathrm{kg}^{-1}\right)$ & $167.94 \pm 71.00$ & 164.79 & $345.31-68.39$ & \\
\hline $\mathrm{V}\left(\mu \mathrm{g} \mathrm{kg}^{-1}\right)$ & $50.15 \pm 36.68$ & 42.14 & $204.77-11.34$ & $0.4355^{* *}$ \\
\hline $\mathrm{Cr}\left(\mu \mathrm{g} \mathrm{kg}^{-1}\right)$ & $150.94 \pm 163.00$ & 119.20 & $746.46-0.25$ & 0.3655 \\
\hline $\mathrm{Co}\left(\mu \mathrm{g} \mathrm{kg}^{-1}\right)$ & $16.42 \pm 10.21$ & 13.79 & $42.51-5.44$ & 0.2576 \\
\hline $\mathrm{Ni}\left(\mu \mathrm{g} \mathrm{kg}^{-1}\right)$ & $0.54 \pm 1.56$ & 0.25 & $8.66-0.25$ & $-0.4813^{* *}$ \\
\hline $\mathrm{Se}\left(\mu \mathrm{g} \mathrm{kg}^{-1}\right)$ & $85.12 \pm 48.24$ & 81.32 & $183.55-15.02$ & $-0.6340^{* *}$ \\
\hline $\mathrm{Cd}\left(\mu \mathrm{g} \mathrm{kg}^{-1}\right)$ & $327.20 \pm 395.66$ & 146.99 & $1550.05-41.36$ & $-0.5187^{* *}$ \\
\hline $\mathrm{Sb}\left(\mu \mathrm{g} \mathrm{kg}^{-1}\right)$ & $32.91 \pm 60.76$ & 8.71 & $239.01-3.24$ & $0.4670^{* *}$ \\
\hline $\mathrm{Pb}\left(\mu \mathrm{g} \mathrm{kg}^{-1}\right)$ & $86.07 \pm 54.38$ & 71.21 & $275.50-36.94$ & $0.4670^{* *}$ \\
\hline $\mathrm{Mn}\left(\mathrm{mg} \mathrm{kg}^{-1}\right)$ & $19.51 \pm 5.55$ & 19.29 & $31.15-10.00$ & -0.1089 \\
\hline $\mathrm{Cu}\left(\mathrm{mg} \mathrm{kg}^{-1}\right)$ & $4.01 \pm 1.25$ & 3.79 & $8.07-2.31$ & $-0.4315^{* *}$ \\
\hline $\mathrm{Zn}\left(\mathrm{mg} \mathrm{kg}^{-1}\right)$ & $12.91 \pm 2.19$ & 12.39 & $19.98-10.68$ & $-0.5921^{* *}$ \\
\hline $\mathrm{Al}\left(\mathrm{mg} \mathrm{kg}^{-1}\right)$ & $9.48 \pm 15.51$ & 4.77 & $78.74-0.03$ & 0.3345 \\
\hline
\end{tabular}




\begin{tabular}{|c|c|c|c|c|}
\hline $\mathrm{Ca}\left(\mathrm{mg} \mathrm{kg}^{-1}\right)$ & $99.36 \pm 21.03$ & 99.86 & $142.64-67.67$ & 0.2980 \\
\hline $\mathrm{Fe}\left(\mathrm{mg} \mathrm{kg}^{-1}\right)$ & $34.66 \pm 21.07$ & 29.64 & $121.79-12.74$ & $0.4168^{* *}$ \\
\hline $\mathrm{K}\left(\mathrm{mg} \mathrm{kg}^{-1}\right)$ & $1859.33 \pm 540.04$ & 1639.14 & $3568.77-1095.80$ & 0.2300 \\
\hline $\mathrm{Mg}\left(\mathrm{mg} \mathrm{kg}^{-1}\right)$ & $806.88 \pm 267.81$ & 719.65 & $1531.50-414.75$ & 0.2310 \\
\hline $\mathrm{Ba}\left(\mathrm{mg} \mathrm{kg}^{-1}\right)$ & $0.51 \pm 0.22$ & 0.49 & $1.18-0.20$ & 0.0458 \\
\hline $\mathrm{Na}\left(\mathrm{mg} \mathrm{kg}^{-1}\right)$ & $41.83 \pm 11.11$ & 39.87 & $80.26-29.17$ & 0.0586 \\
$\mathrm{Sr}\left(\mathrm{mg} \mathrm{kg}^{-1}\right)$ & $0.31 \pm 0.11$ & 0.28 & $0.63-0.16$ & $0.4182 * *$ \\
\hline $\mathrm{B}\left(\mathrm{mg} \mathrm{kg}^{-1}\right)$ & $1.05 \pm 0.31$ & 0.90 & $1.64-0.63$ & 0.3197 \\
\hline
\end{tabular}

${ }^{\text {a}}$ Spearman's rank correlation coefficient between As and other elements; ** significance level ( $\mathrm{p}$ $<0.05)$

\subsection{Comparison between 2006 and 2018 study}

193

194

195
Rice production in Peru is on the rise, for example, between 2006 and 2017 both rice production and area harvested for paddy cultivation increased by 29 and $23 \%$ respectively (based on data published by FAOSTAT (FAO, 2019)). In 2006, authors (Bermejo and Cruz, 2006) had collected five rice samples from the same agricultural fields and As content (420 \pm $109 \mu \mathrm{g} \mathrm{kg}^{-1} ; \mathrm{n}=5$ ) measured using ICP-MS at a private Canadian laboratory (ACME Lab, along with other elements) was found to be significantly higher (based on two-sample t-test) compared to this study (Figure 2 and 4 ).

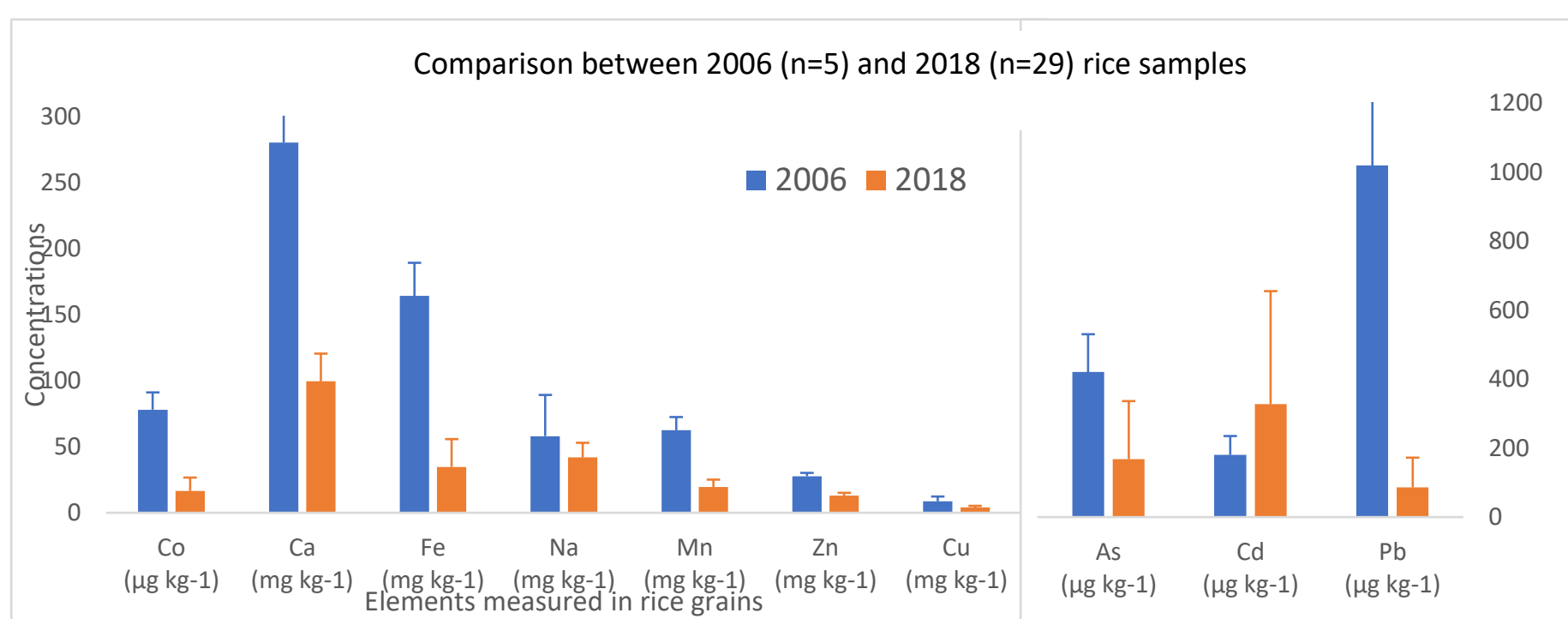

Figure 2: Comparison of analysed elements in rice grains collected between 2006 and 2018 
This could be due to the difference in sample size, exact location of cultivation within the agricultural field, method of cultivation, rice variety and seasonal variation apart from change is As concentrations of the agricultural soil. Indeed, we find a significant (based on twosample t-test) decrease (by 41\%) in As concentration in agricultural soil samples collected between 2006 ( $\mathrm{n}=30)$ and 2018 (Table 3). Furthermore, the control soil samples (n=5) also had reduced concentrations $\left(6.09 \pm 5.73 \mathrm{mg} \mathrm{kg}^{-1}\right.$ in 2018 compared to $14.06 \pm 11.75$ in 2006). Apart from possible reduction in soil As over time this difference could be due to difference in exact location of soil collection between the two surveys (as shown in Figure 3; the soil sampling locations in 2006 in comparison to 2018) and difference in analytical procedures. Plausible explanation for this observed reduction in soil As over time might also include a) periodic flooding of Tumbes river which was more often in 2006 compared to recent times resulting in increased deposition of As and other contaminants due to their presence in river water (Marshall et al., 2018); b) increased crop cycle for rice cultivation between 2006 to 2018 resulting in higher uptake of As by the rice plants; c) change in cultivation method with recent practice allowing weed proliferation which might accumulate As from soil; and d) increased accumulation of As back into the soil due to burning of the rice agricultural residues in the fields as was followed back in time over increased use of fodder for animal feed in recent times, but further studies are needed to investigate the observed reduction. The irrigation water collected in this study had higher As $\left(16.40 \pm 8.41 \mu \mathrm{g} \mathrm{L}{ }^{-1}, \mathrm{n}=5\right)$ compared to $2006(10.40 \pm 10.30 \mu \mathrm{g} \mathrm{L}-1, \mathrm{n}=5)$ so as the drainage sludge but not the drainage water (Figure 4). The increase of As concentration in irrigation water could be an artefact of increased mining activities. As noted by Marshall et al. (2018), the upper Puyango Tumbes river basin includes the mining district of Portovelo with 87 gold processing centres and in their study conducted in 2012-14, authors reported high concentrations of total As along with $\mathrm{Cd}, \mathrm{Cu}, \mathrm{Pb}$ and $\mathrm{Zn}$ in the river water even up to $160 \mathrm{~km}$ downstream from the discharge point. Indeed, 
among all the elements it was only for $\mathrm{Cd}$ and $\mathrm{Pb}$ that we didn't find a significant difference

228 in soil concentrations between this study and 2006 samples, perhaps indicating $\mathrm{Cd}$ and $\mathrm{Pb}$

Ecuador compared to $16.40 \mu \mathrm{g} \mathrm{L}^{-1}$ observed in this study.

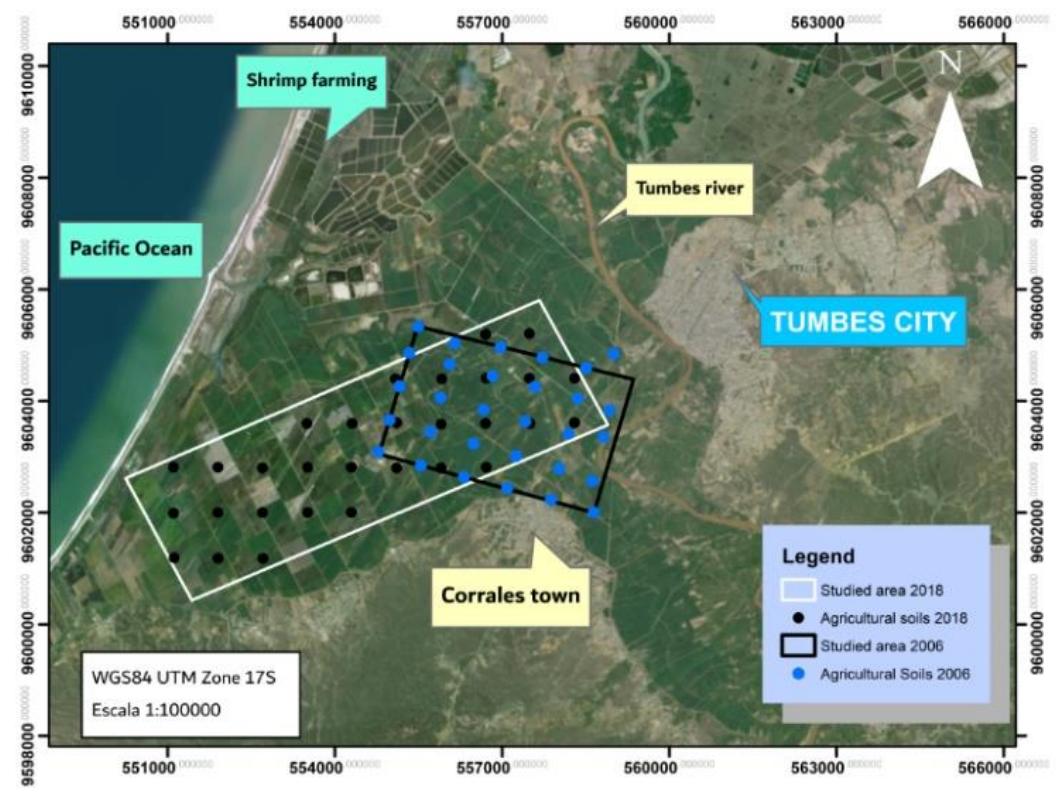

234 Figure 3: Sampling location for agricultural soil samples collected in 2006 (Bermejo and 235 Cruz, 2006) as compared to 2018

236 Table 3: Concentrations of arsenic and of other elements in agricultural soil samples of

237 Tumbes river basin

\begin{tabular}{|l|l|l|l|}
\hline Elements & $\begin{array}{l}\text { Agricultural soils 2006 } \\
(\mathrm{n}=30)\end{array}$ & $\begin{array}{l}\text { Agricultural soils 2018 } \\
(\mathrm{n}=30)\end{array}$ & $\begin{array}{l}\text { Percentage } \\
\text { decrease }^{\mathrm{a}}\end{array}$ \\
\hline & Mean \pm Std. Dev & Mean \pm Std. Dev & \\
\hline $\mathrm{As}\left(\mathrm{mg} \mathrm{kg}^{-1}\right)$ & $14.73 \pm 5.56$ & $8.63 \pm 7.8$ & $41.41 \%$ \\
\hline $\mathrm{Cd}\left(\mathrm{mg} \mathrm{kg}^{-1}\right)$ & $0.97 \pm 0.26$ & $0.89 \pm 0.5$ & $8.25 \%{ }^{\mathrm{b}}$ \\
\hline $\mathrm{Co}\left(\mathrm{mg} \mathrm{kg}^{-1}\right)$ & $14.82 \pm 1.13$ & $3.91 \pm 0.78$ & $73.62 \%$ \\
\hline $\mathrm{Cr}\left(\mathrm{mg} \mathrm{kg}^{-1}\right)$ & $24.8 \pm 3.14$ & $6.32 \pm 1.18$ & $74.52 \%$ \\
\hline $\mathrm{Cu}\left(\mathrm{mg} \mathrm{kg}^{-1}\right)$ & $57.18 \pm 17.44$ & $18.95 \pm 14.27$ & $66.86 \%$ \\
\hline $\mathrm{Mn}\left(\mathrm{mg} \mathrm{kg}^{-1}\right)$ & $490.17 \pm 125.63$ & $165.89 \pm 62.89$ & $66.16 \%$ \\
\hline
\end{tabular}




\begin{tabular}{|l|l|l|l|}
\hline $\mathrm{Mo}\left(\mathrm{mg} \mathrm{kg}^{-1}\right)$ & $1.38 \pm 0.3$ & $1.09 \pm 0.41$ & $21.01 \%$ \\
\hline $\mathrm{Ni}\left(\mathrm{mg} \mathrm{kg}^{-1}\right)$ & $22.26 \pm 3.48$ & $2.63 \pm 0.76$ & $88.19 \%$ \\
\hline $\mathrm{Pb}\left(\mathrm{mg} \mathrm{kg}^{-1}\right)$ & $37.65 \pm 19.39$ & $40.95 \pm 38.26$ & $-8.76 \%{ }^{\mathrm{b}}$ \\
\hline $\mathrm{Zn}\left(\mathrm{mg} \mathrm{kg}^{-1}\right)$ & $137.4 \pm 26.67$ & $43.33 \pm 20.99$ & $68.46 \%$ \\
\hline $\mathrm{Al}(\%)$ & $2.12 \pm 0.27$ & $1.67 \pm 0.37$ & $21.23 \%$ \\
\hline $\mathrm{Ca}(\%)$ & $0.47 \pm 0.12$ & $0.75 \pm 0.52$ & $-59.57 \%$ \\
\hline $\mathrm{Fe}(\%)$ & $3.42 \pm 0.3$ & $3.02 \pm 0.44$ & $11.70 \%$ \\
\hline $\mathrm{K}(\%)$ & $0.21 \pm 0.04$ & $0.17 \pm 0.05$ & $19.05 \%$ \\
\hline $\mathrm{Mg}(\%)$ & $0.62 \pm 0.07$ & $0.55 \pm 0.08$ & $11.29 \%$ \\
\hline $\mathrm{Na}(\%)$ & $0.03 \pm 0.02$ & $0.04 \pm 0.04$ & $-33.33 \%{ }^{\mathrm{b}}$ \\
\hline
\end{tabular}

${ }^{\text {a }}$ Percentage decrease between 2006 and 2018, negative value shows an increase

${ }^{\mathrm{b}}$ No significant difference between 2006 and 2018 concentrations based on two-sample t-test (unequal variance)

Comparison of arsenic concentration in different media between 2006 and 2018
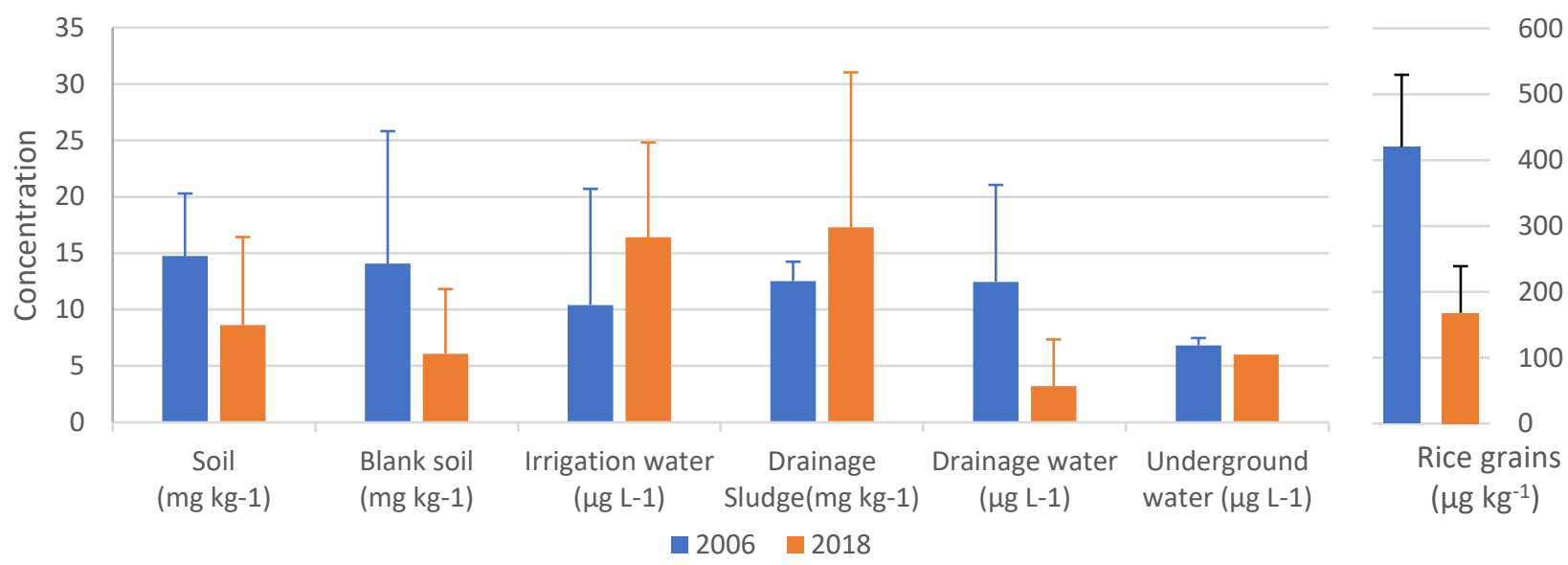

Figure 4: Comparison of arsenic concentrations in different media collected in 2006 and 2018

\subsection{Arsenic and other elements in the agricultural soil of Tumbes river basin}

The contour maps of the study area are displayed in Figure 5 showing the areas with higher

concentration of the elements in red colour and the areas with lower concentrations in yellow.

Concentrations of As along with $\mathrm{Cd}$ and $\mathrm{Pb}$ are found to be higher towards the coastline and as apparent from the maps, As is significantly correlated with $\mathrm{Cd}, \mathrm{Pb}, \mathrm{Zn}$ and $\mathrm{Cu}$ (with Spearman rho of $0.731,0.8861,0.8056$, and 0.8994 respectively $(\mathrm{p}<0.05))$. 
251 While, except for $\mathrm{Cd}, \mathrm{Pb}$ and $\mathrm{Na}$, a significant decrease in elemental concentrations of both

252

253

254

255

256

257

258

259

260

261

262

263

264

265 trace and major elements in soil between 2006 and 2018 was noted (Table 3), none of the potentially toxic elements had mean concentrations (both in 2006 and 2018) above the limit specified by the Peruvian Ministry of Environment which stated $50 \mathrm{mg} \mathrm{kg}^{-1}, 1.4 \mathrm{mg} \mathrm{kg}^{-1}$ and $70 \mathrm{mg} \mathrm{kg}^{-1}$ as safe limit for $\mathrm{As}, \mathrm{Cd}$ and $\mathrm{Pb}$ respectively for agricultural soil (MINAM, 2018). But with maximum concentration recorded of $3.06 \mathrm{mg} \mathrm{kg}^{-1}$ in this 2018 study, four samples had $\mathrm{Cd}$ greater than the safe limit, and two of the $\mathrm{Pb}$ soil exceeded the limit with maximum concentration recorded $212.4 \mathrm{mg} \mathrm{kg}^{-1}$. Though soil As was positively correlated with Cd and $\mathrm{Pb}$, rice As was positively correlated with $\mathrm{Pb}$ but negatively correlated with $\mathrm{Cd}$ (Table 2). When PCA was applied to the soil data to explore similarities in behaviour of the elements, first two principle components extracted (Figure 6), explained approximately 65\% (PC1: $40.52 \%$; PC2 $25.05 \%$ ) of the information contained in the initial variables while the five components together explained more than $90 \%$ of the variability observed. It is visible from Figure 6 that As was not associated with the soil properties including texture, $\mathrm{pH}$ and redox potential and was more associated with elements such as $\mathrm{Pb}, \mathrm{Cd}, \mathrm{Zn}, \mathrm{Se}$ and $\mathrm{Sb}$. Further studies looking at interrelationship of uptake of elements by rice depending on the variety cultivated in this area along with soil proprieties, will explain potential combined hazard and health risk, if any, from Peruvian rice consumption. 

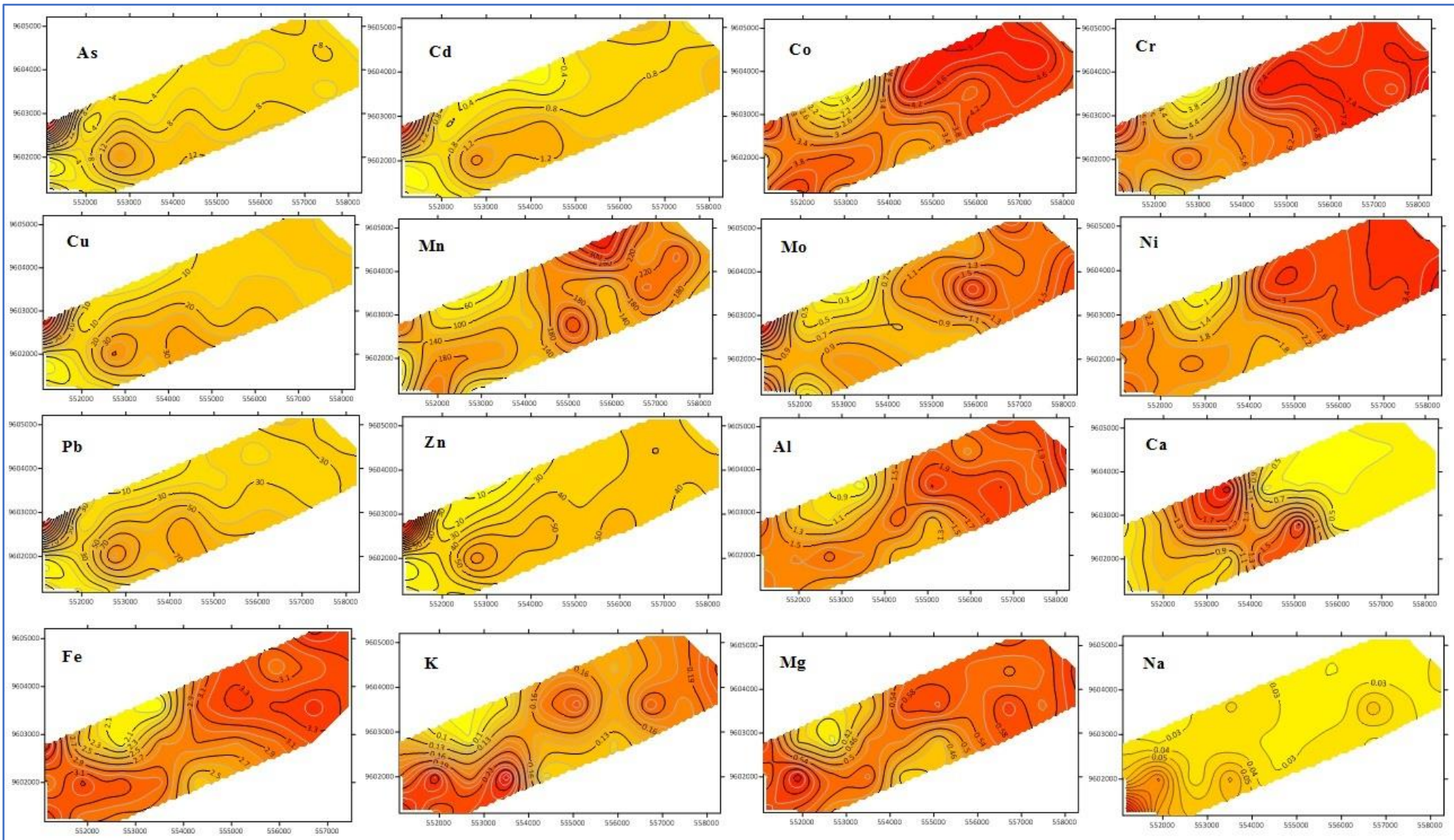

270 Figure 5: Geochemical distribution map of trace and major elements in the surveyed

271 agricultural field area in Tumbes river basin

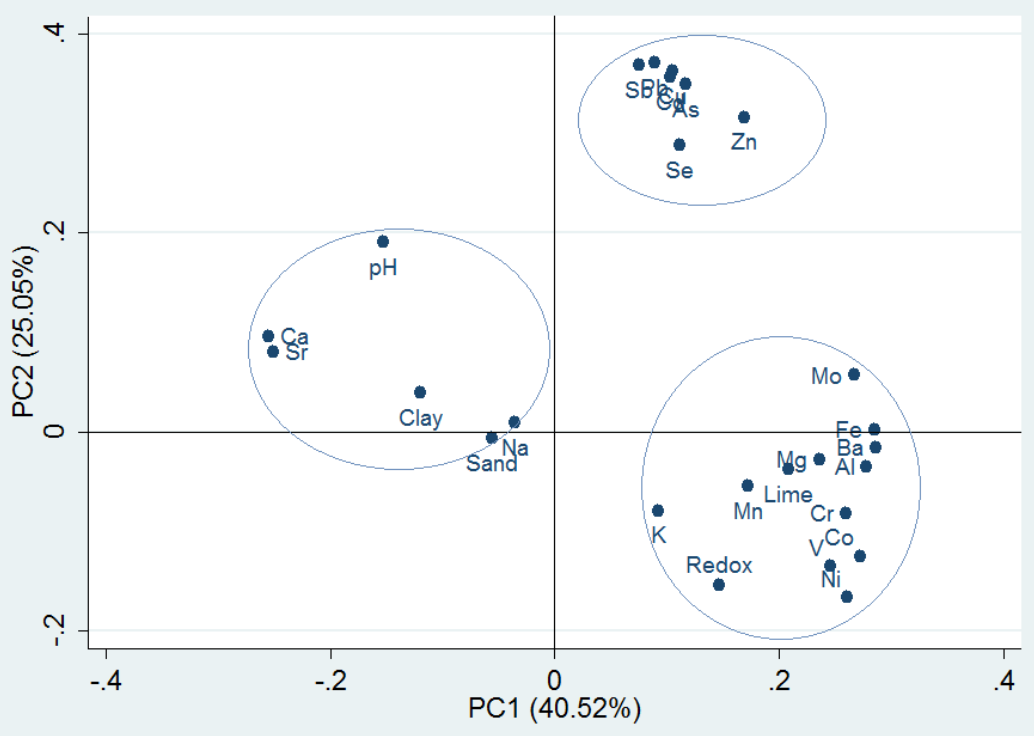

273 Figure 6: Principal component analysis diagram for average elemental concentrations and

274 other parameters measured in soil samples of agricultural fields in Tumbes river basin 


\subsection{Transfer of potentially toxic elements in rice grain}

276 Based on the ratios of heavy metal concentration in rice grains over 12 matched soil samples,

277 the transfer factors TFgrain/soil were calculated (Table 4). The average TFgrain/soil had the

278 trend $\mathrm{Cd}>\mathrm{Zn}>\mathrm{Cu}>\mathrm{Mn}>\mathrm{Cr}>\mathrm{As}>\mathrm{Co}>\mathrm{Pb}$ which was similar to previous studies (Zeng et al.,

279 2015; Lu et al., 2018; Mao et al., 2019) and As transfer ratio of $0.025 \pm 0.018$ is similar to the

280 study in Yangtze river delta in China (0.020 \pm 0.001 ; Mao et al. (2019)).

281 Table 4: Transfer factor of potentially toxic elements in rice grain $(n=12$, matched paired

282 samples)

\begin{tabular}{|c|c|c|c|c|c|c|c|c|}
\hline Sample & As & Cd & Co & $\mathrm{Cu}$ & $\mathrm{Cr}$ & Mn & $\mathbf{P b}$ & Zn \\
\hline GA15-SA28 & 0.0154 & 0.1386 & 0.0057 & 0.1814 & 0.0000 & 0.1433 & 0.0022 & 0.3417 \\
\hline GA13-SA26 & 0.0512 & 0.1884 & 0.0106 & 0.3325 & 0.0337 & 0.1003 & 0.0080 & 0.3728 \\
\hline GA11-SA22 & 0.0627 & 0.1668 & 0.0103 & 0.3484 & 0.1637 & 0.1851 & 0.0138 & 0.5287 \\
\hline GA18-SA23 & 0.0048 & 0.0891 & 0.0031 & 0.1087 & 0.0012 & 0.0640 & 0.0007 & 0.1888 \\
\hline GA09-SA21 & 0.0102 & 1.3479 & 0.0041 & 0.3219 & 0.0117 & 0.1119 & 0.0018 & 0.2782 \\
\hline GA10-SA20 & 0.0325 & 0.0944 & 0.0021 & 0.1393 & 0.0001 & 0.0911 & 0.0013 & 0.2674 \\
\hline GA08-SA17 & 0.0092 & 0.3785 & 0.0030 & 0.2122 & 0.0000 & 1.3185 & 0.0008 & 0.2957 \\
\hline GA16-SA18 & 0.0238 & 0.7196 & 0.0013 & 0.3042 & 0.0064 & 0.1143 & 0.0017 & 0.3272 \\
\hline GA17-SA18 & 0.0150 & 0.1532 & 0.0020 & 0.2297 & 0.0062 & 0.1157 & 0.0019 & 0.3383 \\
\hline GA03-SA09 & 0.0200 & 0.1709 & 0.0021 & 0.2544 & 0.0276 & 0.0977 & 0.0019 & 0.2753 \\
\hline GA02-SA08 & 0.0397 & 0.2425 & 0.0031 & 0.2704 & 0.0024 & 0.0415 & 0.0079 & 0.2416 \\
\hline GA06-SA15 & 0.0199 & 1.4360 & 0.0057 & 0.3725 & 0.0596 & 0.0799 & 0.0036 & 0.4352 \\
\hline Mean \pm SD & $\begin{array}{r}0.025 \\
\pm \\
0.018\end{array}$ & $\begin{array}{r}0.427 \\
\pm \\
0.483\end{array}$ & $\begin{array}{r}0.004 \pm \\
0.003\end{array}$ & $\begin{array}{r}0.256 \pm \\
0.084\end{array}$ & $\begin{array}{r}0.026 \pm \\
0.047\end{array}$ & $\begin{array}{r}0.205 \pm \\
0.352\end{array}$ & $\begin{array}{r}0.004 \pm \\
0.004\end{array}$ & $\begin{array}{r}0.324 \pm \\
0.091\end{array}$ \\
\hline Range & $\begin{array}{r}0.005- \\
0.063\end{array}$ & $\begin{array}{r}0.089- \\
1.436\end{array}$ & $\begin{array}{r}0.001- \\
0.011\end{array}$ & $\begin{array}{r}0.109- \\
0.373\end{array}$ & $\begin{array}{r}0.000- \\
0.164\end{array}$ & $\begin{array}{r}0.042- \\
1.318\end{array}$ & $\begin{array}{r}0.001- \\
0.014\end{array}$ & $\begin{array}{r}0.189 \\
0.529\end{array}$ \\
\hline
\end{tabular}

283

\section{Conclusions}

285 This study confirms the presence of As in Peruvian rice produced in a major paddy

286 cultivation area of Tumbes river basin in northern Peru. While the grain As levels were not

287 highly elevated, the As content of few samples $(\mathrm{n}=7)$ greater than $200 \mu \mathrm{g} \mathrm{kg}^{-1}$ arguably could 
contribute negatively to human health upon chronic exposure. In addition, our data provides a baseline of grain-As concentrations in a country and in particular a province where appreciable agricultural intensification has taken place. Since Peruvian rice production is on a steep rise, this results demand for further comprehensive investigation covering all rice cultivation areas in Peru. Arsenic TF grain/soil observed is this study was similar to previous studies in other countries, hence further studies should address potential factors including different rice genotypes affecting uptake of As by the rice plant. It was worth noting that we found a substantial decrease in As content in rice collected in this study when compared to samples collected from same agricultural fields in 2006 along with significant decrease in soil As content. But compared to 2006 study, there was a rise in As concentration in the irrigation water which comes from Tumbes river, and this could be attributed to increased mining activities in the upper Puyango-Tumbes river basin which includes the mining district of Portovelo. Further studies should focus of As induced health risks in Tumbes river basin attributed to arsenic exposure not only from drinking water which is often collected from the river but also from rice, cultivated and consumed locally. Besides, presence of inorganic As in different genotypes as well as As bioaccessibility study from rice varieties cultivated in Peru could help understand the actual scenario of contamination as well as realistic exposure and risk assessment.

\section{Acknowledgement}

GJFC acknowledges receipt of Researcher Links-Travel Grant by National Council of Science, Technology and Technological Innovation (CONCYTEC) (Contract $\mathrm{N}^{\circ}$ 160-2018FONDECYT) supporting visit to University of Salford. This work was supported by UKIERI award (IND/CONT/G/16-17/93) to DM. We acknowledge and thank Universidad Nacional de Tumbes for supporting DM's visit to Tumbes. Instrument support from the GCER, The University of Newcastle is highly appreciated. 


\section{Competing interests}

314 The authors declare that they have no competing/conflicting interests.

\section{References}

Banerjee M, Banerjee N, Bhattacharjee P, Mondal D, Lythgoe PR, Martínez M, et al. High arsenic in rice is associated with elevated genotoxic effects in humans. Scientific reports 2013; 3: 2195.

Bermejo LA, Cruz GJF. Heavy metals in rice in left side of Tumbes river, Peru. Manglar 2006; 4: 45-50.

Bundschuh J, Litter MI, Parvez F, Roman-Ross G, Nicolli HB, Jean JS, et al. One century of arsenic exposure in Latin America: a review of history and occurrence from 14 countries. Sci Total Environ 2012a; 429: 2-35.

FAO. http://www.fao.org/faostat/en/\#compare. 2019. Food Administration Organization, 2019.

George CM, Sima L, Arias MH, Mihalic J, Cabrera LZ, Danz D, et al. Arsenic exposure in drinking water: an unrecognized health threat in Peru. Bull World Health Organ 2014; 92: 565-72. 
INEI. Consumo de Alimentos y Bebidas. 2019. Instituto Nacional de Estadística e Informática, Peru, 2012.

Kato LS, Fernandes EADN, Raab A, Bacchi MA, Feldmann J. Arsenic and cadmium contents in Brazilian rice from different origins can vary more than two orders of magnitude. Food chemistry 2019; 286: 644-650.

Lu A, Li B, Li J, Chen W, Xu L. Heavy metals in paddy soil-rice systems of industrial and township areas from subtropical China: Levels, transfer and health risks. Journal of Geochemical Exploration 2018; 194: 210-217.

Mao C, Song Y, Chen L, Ji J, Li J, Yuan X, et al. Human health risks of heavy metals in paddy rice based on transfer characteristics of heavy metals from soil to rice. Catena 2019; 175: 339-348.

Marshall BG, Veiga MM, Kaplan RJ, Adler Miserendino R, Schudel G, Bergquist BA, et al. Evidence of transboundary mercury and other pollutants in the Puyango-Tumbes River basin, Ecuador-Peru. Environ Sci Process Impacts 2018; 20: 632-641.

McClintock TR, Chen Y, Bundschuh J, Oliver JT, Navoni J, Olmos V, et al. Arsenic exposure in Latin America: biomarkers, risk assessments and related health effects. Sci Total Environ 2012; 429: 76-91.

Meharg AA, Zhao F-J. Risk from arsenic in rice grain. Arsenic \& Rice. Springer, 2012, pp. 31-50.

MINAM. Aprueban Estandares de Calidad Ambiental (ECA) para Suelo. In: Environment PMo, editor. Decreto Supremo Nº11-2017-MINAM. Diario El Peruano, Peru, 2018, pp. 12-15.

Mondal D, Banerjee M, Kundu M, Banerjee N, Bhattacharya U, Giri AK, et al. Comparison of drinking water, raw rice and cooking of rice as arsenic exposure routes in three contrasting areas of West Bengal, India. Environ Geochem Health 2010; 32: 463-77. 
Mondal D, Mwale T, Xu L, Matthews H, Oyeka A, Lace-Costigan G, et al. Risk perception of arsenic exposure from rice intake in a UK population. Palgrave Communications $2019 ; 5$.

Mondal D, Polya DA. Rice is a major exposure route for arsenic in Chakdaha block, Nadia district, West Bengal, India: A probabilistic risk assessment. Applied Geochemistry 2008; 23: 2987-2998.

Mwale T, Rahman MM, Mondal D. Risk and Benefit of Different Cooking Methods on Essential Elements and Arsenic in Rice. Int J Environ Res Public Health 2018; 15.

Otero X, Tierra W, Atiaga O, Guanoluisa D, Nunes LM, Ferreira T, et al. Arsenic in rice agrosystems (water, soil and rice plants) in Guayas and Los Ríos provinces, Ecuador. Science of the Total Environment 2016; 573: 778-787.

Rahman MA, Hasegawa H, Rahman MA, Rahman MM, Miah MAM. Influence of cooking method on arsenic retention in cooked rice related to dietary exposure. Science of The Total Environment 2006; 370: 51-60.

Rahman MA, Rahman MM, Reichman SM, Lim RP, Naidu R. Arsenic Speciation in Australian-Grown and Imported Rice on Sale in Australia: Implications for Human Health Risk. Journal of Agricultural and Food Chemistry 2014; 62: 6016-6024.

Roychowdhury, T., Uchino, T., Tokunaga, H. and Ando, M. Survey of arsenic in food composites from an arsenic-affected area of West Bengal, India. Food and Chemical Toxicology 2002; 40(11): 1611-1621.

Silva MR. Evaluación del grado de afectación de la calidad del agua del Rio Tumbes y propuesta de recuperación Sector Peruano-año 2011 AL 2014. Escuela de Postgrado. Master. Universidad Nacional de Tumbes, Tumbes - Peru, 2018, pp. 93.

U.S. EPA.“Method 3051A (SW-846): Microwave Assisted Acid Digestion of Sediments, Sludges, and Oils,” 2007; Revision 1. Washington, DC. 

Res Public Health 2015; 12: 15584-93.

390 